\title{
EFFECT OF DIFFERENT SPAWN SEED ON GROWTH AND VARIETIES OF THE OYSTER MUSHROOMS (Pleurotus spp.)
}

\author{
Farida Akter ${ }^{1 \star}$, Kamal Uddin Ahmed ${ }^{2}$ and Nuruddin Miah ${ }^{2}$ \\ 1Jute Seed Division, Bangladesh Agricultural Development Corporation (BADC) Dhaka- \\ 1000, Bangladesh; 'Department of Biochemistry, Sher-e Bangla Agricultural University, \\ Dhaka-1207, Bangladesh.
}

*Corresponding author: Farida Akter; E-mail: adfaridaakter@gmail.com

\begin{tabular}{|c|c|}
\hline ARTICLE INFO & A B S T R A C T \\
\hline $\begin{array}{l}\text { Received } \\
18 \text { July, } 2019\end{array}$ & $\begin{array}{l}\text { The effect of different spawn seed on different variety show significant effect on mycelia } \\
\text { running rate of oyster mushroom that reduced the required days to complete mycelium }\end{array}$ \\
\hline Revised & running in the spawn packet compared to the sawdust alone. Effect of different spawn \\
\hline 07 August, 2019 & seed on different variety found to be significant in yield contributing characters and yield \\
\hline $\begin{array}{l}\text { Accepted } \\
27 \text { August, } 2019\end{array}$ & $\begin{array}{l}\text { of oyster mushroom with some extent. The highest biological yield, economic yield, dry } \\
\text { yield, biological efficiency (BE) and benefit cost ratio (BCR) } 264.9 \mathrm{~g}, 259.3 \mathrm{~g}, 25.17 \mathrm{~g} \text {, } \\
86.90,9.11 \% \text { respectively was observed in maize based spawn seed on the Pleurotus }\end{array}$ \\
\hline $\begin{array}{l}\text { Online } \\
31 \text { August, } 2019\end{array}$ & $\begin{array}{l}\text { florida variety. Effect of different spawn seed on different variety has a profound effect } \\
\text { on chemical composition of oyster mushroom. Considering all the parameters in this }\end{array}$ \\
\hline $\begin{array}{l}\text { Key words } \\
\text { Spawn seed }\end{array}$ & experiment, maize based spawn seed on the Pleurotus florida variety is found \\
\hline Growth & ality \\
\hline Varieties & of fruiting body. Wheat based spawn seed on the Pleuorotus ostreatus variety may be \\
\hline Mushro & \\
\hline
\end{tabular}

To cite this article: Akter F, KU Ahmed and N Miah, 2019. Effect of different spawn seed on growth and varieties of the oyster mushrooms (Pleurotus spp.). Res. Agric. Livest. Fish. 6 (2): 181-192.

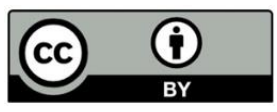

Copy right $\odot$ 2019. The Authors. Published by: AgroAid Foundation This is an open access article licensed under the terms of the Creative 


\section{INTRODUCTION}

Mushroom plants are classified in the group of fungi and the term mushroom is used to mean these large fleshy fungi. They may be seen growing on the trunks of trees, on stumps or logs, coming out of leaf mold on forest floor or in the grass in yards, lawn, field and pasture or along the road sides. Mushroom is large reproductive structures of edible saprophytic fungi belonging to the class of basidiomycetes or ascomycetes of nearly 50000 valid species of fungi and about more than 2000 of prime edible mushrooms about so have been grown experimentally and 25 accepted widely as food. However 32 varieties have been brought under commercial cultivation and 4-5 produced on industrial scale throughout the world. The vegetative part of mushroom consists of thread like long mycelium which under suitable condition forms fruiting bodies or sporocarps. Mushrooms are being used as food and medicine since time immemorial. Mushrooms are the health food of the world. They are rich in proteins, vitamins and minerals, so they are consumed as energy rich food. Fresh mushrooms contain about $85 \%$ water and $3.2 \%$ protein. But dried mushrooms water content is low and protein level is high as 34 to $44 \%$ comprising all the essential amino acids and the fat content is less than $0.3 \%$. There are about 100 species of edible mushrooms all over the world. Unfortunately, it is realized that mushrooms did not receive universal acceptance over the years since a number of naturally growing mushrooms are poisonous. Now the situation has been changed because the cultivated edible mushrooms are totally safe for human consumption.

Mushroom cultivation fits in very well with sustainable farming and has several advantages, it uses agricultural waste products, a high production per surface area can be obtained, after picking; the spent substrate is still a good soil conditioner. They have less carbohydrate so they are believed to be suitable for diabetic patients. Mushrooms are very popular in most of the developed countries and they are becoming popular in many developing countries like India. Applications and market for mushrooms is growing rapidly in India because of their nice aroma, nutritious values, subtle flavour and many special tastes. Edible mushrooms are recommended by the FAO as loud, to meet protein requirement of developing countries. The large portion of which depends mainly on cereals since animal proteins are beyond the reach of common people in our country. Mushroom can play important role in minimizing that deficiency. Mushroom reduces serum cholesterol and high blood pressure (Mori, 1986). Edible mushroom have been treated as important tool in modern medicine for their medicinal values (Kovfeen, 2004). Anti-cancer medicine (Leutinun) is produced recently by some chemical companies from the extract (Polysaccharides) of shitake mushroom (Mori, 1986). Most of the people of Bangladesh have been suffering from malnutrition. Mushroom could substantiate the suffering from malnutrition to some extent.

The enormous increase in our population has necessitated more and more food production through alternate resources such as mushroom as the availability of more arable land. In the developed countries, mushrooms have become one of the most important horticultural crops (Alam and Saboohi, 2001). Mushroom is short duration and land saving crop. It grows independent of sunlight, relatively fast growing, does not require fertile soil since grown on composted or non-composted agro wastes as wheat and paddy straw, banana leaves, sugarcane bagasse and leaves, wheat etc. It needs labor intensive indoor activity, which can help the landless, small and marginal farmers to raise their income, diversify economic activity and create gainful employment, especially for unemployed / under employed youth and women folk. So it can be welcomed by the poor and marginal farmers. The mushroom cultivation could be a profitable agribusiness. Mushroom farm offer a valuable services to the livestock and poultry sectors by transforming agricultural byproducts. Substrate is one of the most important parameter in mushroom production, as mushrooms depend on substrates for nutrition and the substrate is normally a source of lignocellulose material which supports growth, development and fruiting of mushroom. The substrates used for mushroom production are excellent source of organic fertilizers. Mushroom production converts agricultural wastes into a high protein source for human (Labuschagne et al. 2000). Our country has resources and potential for large scale production of mushroom both for consumption and export. Variety is most prominent factor for better yield. In this experiment the findings of different variety on different substrates are observed. Substrates are important for nutritional status of mushroom. Thus the present study has been carried out to know the suitable spawn seed on different variety for growing oyster mushroom and prepare suitable spawn seed for mushroom production in Bangladesh to increase the yield. The cost benefit ratio of the spawn packet was also measured. 


\section{MATERIALS AND METHODS}

\section{Experiment site}

The experiment was carried out at the Biochemistry Laboratory and Mushroom Culture House (MCH) of the Department of Biochemistry, Sher-e Bangla Agricultural University, Dhaka, During November, 2011 to April, 2011. Vegetative seed or spawn of Oyster mushroom was collected and generated by subculture in $\mathrm{MCH}$. The generated subculture spawn were used in different treatment and experiment.

\section{Experiments and treatments}

Experiment with nine treatments with three replications was conducted to achieve the objectives. The treatments were as follows:

$\begin{array}{ll}\mathrm{T}_{1} \mathrm{C} & \text { : Chickpea + Pleurotus cystidiosus } \\ \mathrm{T}_{2} \mathrm{C} & : \text { Maize }+ \text { Pleurotus cystidiosus } \\ \mathrm{T}_{3} \mathrm{C} & : \text { Wheat }+ \text { Pleurotus cystidiosus } \\ \mathrm{T}_{1} \mathrm{~F} & : \text { Chickpea }+ \text { Pleurotus florida } \\ \mathrm{T}_{2} \mathrm{~F} & : \text { Maize }+ \text { Pleurotus florida } \\ \mathrm{T}_{3} \mathrm{~F} & : \text { Wheat }+ \text { Pleurotus florida } \\ \mathrm{T}_{1} \mathrm{PO} 2 & : \text { Chickpea + Pleurotus ostreatus } \\ \mathrm{T}_{2} \mathrm{PO} 2 & : \text { Maize }+ \text { Pleurotus ostreatus } \\ \mathrm{T}_{3} \mathrm{PO} 2 & : \text { Wheat }+ \text { Pleurotus ostreatus }\end{array}$

\section{Sterilization}

In the Laboratory, all instruments, glassware and culture media were sterilized by autoclaving for maintaining sterility. The bottles containing the media and also spawn packets were autoclaved with 15 PSI at $121^{\circ} \mathrm{C}$ for 1-2 hours. The culture media were allowed to be cold under normal condition after autoclaving. The culture room of the laboratory was cleaned by gently washing with detergent followed by $70 \%$ ethyl alcohol regularly. Before inoculation, Laminer airflow cabinet was sterilized using ultraviolet light for 30 minutes keeping blower active.

\section{Conduction of the experiment}

\section{Preparation of PDA media}

At first, $250 \mathrm{~g}$ potatoes were washed, peeled and sliced to prepare $1000 \mathrm{ml}$ PDA media. Then peeled and sliced potatoes were boiled in water to make them soft and also filtered through a cheese cloth. Further water was added to get $1000 \mathrm{ml}$ media. After adding $18 \mathrm{~g}$ agar and $20 \mathrm{~g}$ dextrose, it was heated and stirred for about 45 minutes. Then $10 \mathrm{ml}$ media was taken into each of the test tube and mouths of the test tubes were plugged with cotton and brown paper. After that all the test tubes were sterilized in an autoclave for 20 minutes at $121^{\circ} \mathrm{C}$ and $1.5 \mathrm{~kg} / \mathrm{cm}$ pressure (Figure 1 ).

\section{Preparation of mother spawn}

Mother culture substrate was prepared by using sawdust. Sawdust was sieved and sun dried. The mother culture substrate was prepared by sawdust and wheat bran in $2: 1$ ratio with $0.1 \%$ calcium carbonate (Ruhul Amin, 2002). Then it was mixed thoroughly with hands and maintained $55 \%$ moisture content by adding sufficient water. Then $200 \mathrm{gm}$ of mixture was packed tightly $18 \times 25 \mathrm{~cm}$ polypropylene (PP) bag. Each of the bags was prepared by using bamboo neck and plugged the neck with cotton and covered with brown paper placing rubber band to hold it tightly in place. The packets were sterilized for 1 hour at $121^{\circ} \mathrm{C}$ with $1.5 \mathrm{~kg} / \mathrm{cm}^{2}$ pressure in an autoclave and kept them for cooling. Then inocula from pure culture were placed aseptically to the mother spawn packets. The packets after inoculation were again plugged with cotton and were kept at 20$22^{\circ} \mathrm{C}$ for spawn running. The whole packet containing substrate became white due to fungal mycelia proliferation within 15-20 days and thus ready for spawning the substrate (Figure 2). 


\section{Low cost spawn production of Oyster mushroom}

\section{Preparation of substrates and packets}

Spawn packets using different substrates were prepared separately. With spawn preparing substrate; different supplements (at the different rate on dry weight basis) and $\mathrm{CaCO} 3$ (1g per packet) was added. The measured materials were taken in a plastic bowl and mixed thoroughly by hand and moisture was increased by adding water. Moisture was measured by using the moisture meter and adjusted the moisture content at $65 \%$. The mixed substrates were filled into $7 \times 11$ inch polypropylene bag @ $500 \mathrm{~g}$. The filled polypropylene bags were prepared by using bamboo neck and plugged the neck with cotton and covered with brown paper placing rubber band to hold it tightly in place (Figure 3 ).

\section{Sterilization, inoculation and mycelium running in spawn packets}

Therefore the packets were sterilized about $1 \mathrm{hrs}$ and then these were kept for cooling. After cooling, $5 \mathrm{~g}$ mother spawn were inoculated into the packets in the laminar airflow cabinet and were kept at $20-22^{\circ} \mathrm{C}$ temperature until the packets become white with the mushroom mycelium. After completion of the mycelium running the rubber band, brown paper, cotton plug and bamboo neck of the mouth of spawn packet were removed and the mouth was wrapped tightly with rubber band. Than this spawn packets were transferred to the culture house (Figure 4).

\section{Cultivation of spawn packet}

Two ends, opposite to each other of the upper position of plastic bag were cut in "D" shape with a blade and opened by removing the plastic sheet after which the opened surface of substrate was scraped slightly with a tea spoon for removing the thin whitish mycelial layer. Then the spawn packets were soaked in water for 15 minutes and invested to remove excess water for another 15 minutes. The packets of each type were placed separately on the door of culture room and covered with the newspaper. The moisture of the culture room was maintained 80-85 on relative humidity by spraying water 3 times a day. The light around 300-500 lux and ventilation of culture house was maintained uniformly. The temperature of culture house was maintained $22^{\circ} \mathrm{C}$ to $25^{\circ} \mathrm{C}$. The first primordia appeared $2-4$ days after scribing depending upon the type of substrate. The harvesting time also varied depending upon the type of substrate (Figure 5-6).

\section{Collection of produced mushrooms}

Oyster mushrooms matured within 2-3 days after primordia initiation. The matured fruiting body was identified by cural margin of the cap. Mushrooms were harvested by twisting to uproot from the base (Figure 8).

\section{Data collection}

Mycelial growth was counted by taking the full packet as a full unit and generally the data was taken at every two days intervals. Mycelium running rate (MRR) for each type of substrate was measured after the mycelium colony cross the shoulder of the packet. The linear length was measured at different places of packet.

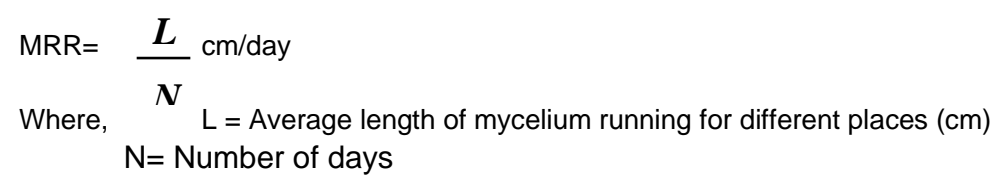

Days required from inoculation to completion of mycelium running were measured. Number of welldeveloped fruiting body was included in counting. Number of very well-developed fruiting body was recorded. Tiny fruiting bodies were discarded from counting. Average weight of individual fruiting body was calculated by dividing the total weight of fruiting body per packet by the total number of fruiting body per packet. Thickness of the pileus of three randomly selected fruiting bodies was measured using a slide calipers. Diameter of pileus, length and diameter of stalk, thickness of pileus were also measured. 

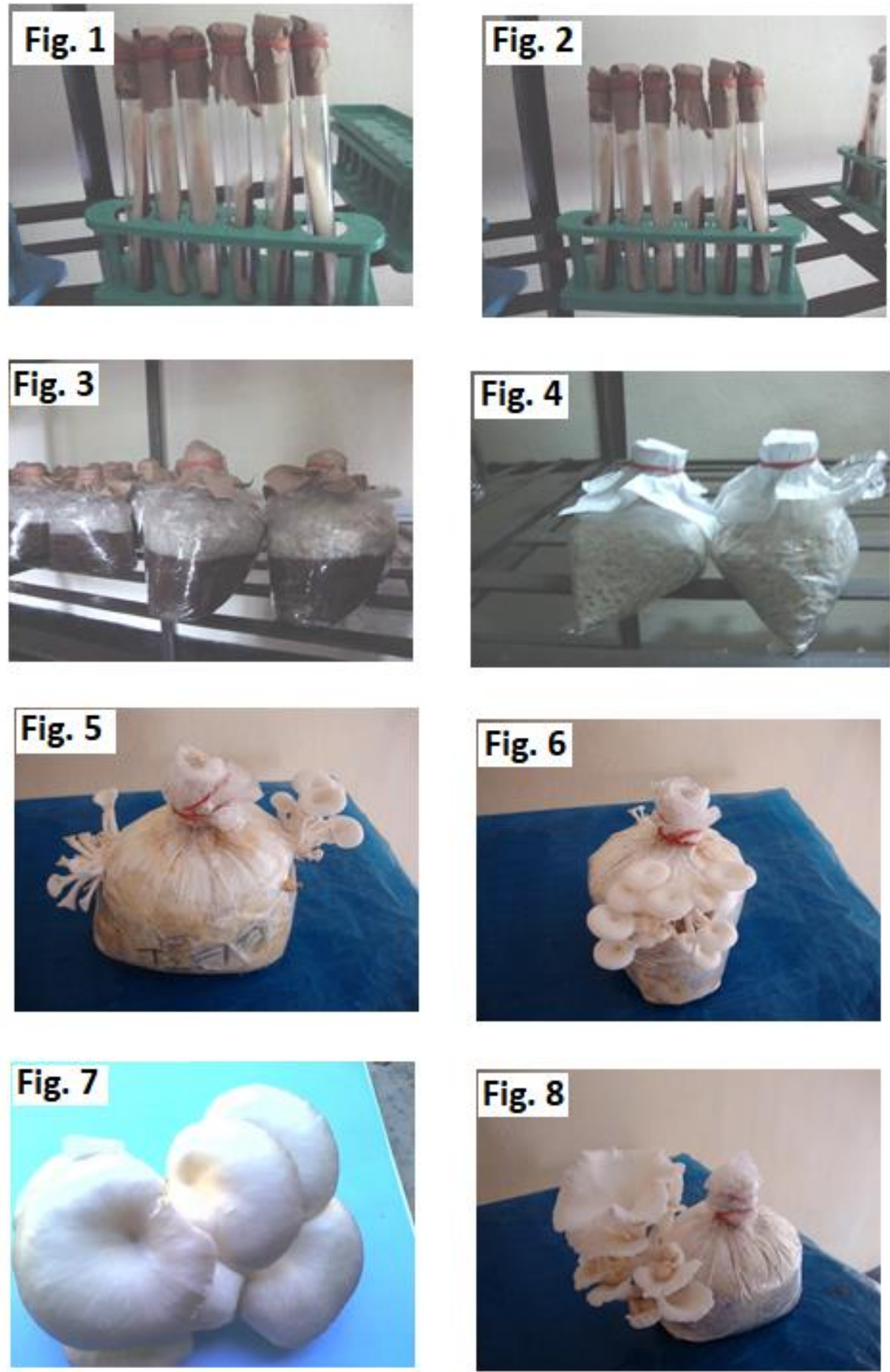

Figures (1-8): Fig. 1: Different type of Munhroom culture- Tissue planted in the PDA media; Fig. 2: Pure Culture of Pleurotus ostreatus; Fig. 3: Spawn Packet culture; Fig. 4: Vegetative Seed of mushroom; Fig. 5: Pin head primordial in the spawn packet; Fig. 6: Young fruiting body in the spawn packet; Fig. 7: Matured fruiting body in the spawn packet; Fig. 8: Fruiting body harvested from the spawn packet. 


\section{Biological and economic yield}

Biological yield per $500 \mathrm{~g}$ packet was measured by weighing the whole cluster of fruiting body without removing the lower hard and dirty portion. Economic yield per $500 \mathrm{~g}$ packet was recorded by weighing all the fruiting bodies in a packet after removing the lower hard and dirty portion.

\section{Dry yield}

About $50 \mathrm{~g}$ of randomly selected mushroom sample was taken in a paper envelop and was weighed correctly. The mushroom was oven dried at $72^{\circ} \mathrm{C}$ temperature for 24 hours and weighed again. The weight of blank envelop was subtracted from both the weight. The dry yield was calculated using the following formula:

Oven dry weight of sample $(\mathrm{g})$

Dry yield $(\mathrm{g} / 500 \mathrm{~g}$ packet $)=$ Economic yield

$$
\text { Fresh weight of sample }(\mathrm{g})
$$

\section{Biological efficiency}

Biological efficiency was determined by the following formula

$$
\text { Total biological weight sample }(\mathrm{g}) \times 100
$$

Biological efficiency $=$

$$
\text { Total weight substrate used }(\mathrm{g})
$$

\section{Cost benefit ratio}

The benefit cost ratio for different low cost substrate were computed based on present market price of mushroom and cost of different inputs in the markets (Sarker, 2004).

\section{Drying of mushrooms}

The collected fruiting bodies of the mushroom are transferred to the laboratory. Therefore data are collected on different parameter. After collection of the data the fruiting bodies are dried in the sun separately treatment wise. In the time of drying the stipe and the pileus are separated for better drying.

\section{Cultural operations for subsequent flushes}

After completing the first harvest again the packets were scraped at the place where the 'D' shaped cut had been done and were soaked in a bucket for five minutes and then placed in the culture house and water was sprayed regularly. The primordia appeared 9-10 days after first harvest and 7-8 days after second harvest. Water spraying was continued until the mushrooms were ready to be harvested.

\section{Statistical analysis of data}

The experiment was laid out in single factor CRD (Complete Randomized Design). The experiment considered experiments with 5 treatments with 3 replications and 3 spawn packets in each replication. The data for the characters considered in the present experiments were statistically analyzed following the Complete Randomized Design (CRD). The analysis of variance was conducted and means were compared following least significant difference (LSD) test at $1 \%$ and $5 \%$ level of probability for interpretation of results (Gomez and Gomez, 1984).

\section{RESULTS AND DISCUSSION}

\section{Effect on mycelium growth}

The effect of different spawn on different variety showed significant effect on mycelial running rate of oyster mushroom that reduced the required days to complete mycelium running in the spawn packet compared to the sawdust alone. Maize and wheat with Pleurotus florida variety showed the highest rate of mycelium running and lowest in chickpea with Pleurotus cystidiosus variety. The required days to complete mycelium running in the spawn packet are statistically similar in all the treatment. Days required to complete mycelium running is higher in chickpea Pleurotus cystidiosus and lower in wheat with pleurotus ostreatus. 
Mycelium running rate per day (MRR) for each type of spawn was measured after the mycelium colony crossed the shoulder of the packet. The linear length was measured at different places of packet. Mycelium running rate in spawn packet was found to be different due to different supplements used. The highest running rate was observed in $T_{3} F$ and $T_{1} P(0.62 \mathrm{~cm})$ followed by $T_{1} F(0.61 \mathrm{~cm}), T_{2} F(0.613 \mathrm{~cm})$ and $T_{2} P(0.60 \mathrm{~cm})$ and the lowest running rate of mycelium was observed in $\mathrm{T}_{1} \mathrm{C}(0.50 \mathrm{~cm})$ (Table 1). Days to complete mycelium running in spawn packet ranged from 19.67 to 31.83 days on different supplements to spawn (Table 1). Significantly the lowest days to complete mycelium running was recorded on $T_{2} P$ (19.67) followed by $T_{3} P$ (20.00), $T_{1} P$ (20.67), $T_{2} F$ and $T_{1} C(21)$. Days for completing the mycelium running on other treatments were statistically in different and significantly lower as compared to control. Maximum days required to complete mycelium running was on $\mathrm{T}_{1} \mathrm{C}$ (31.83) and $\mathrm{T}_{3} \mathrm{C}$ (25.67).

The highest time from stimulation to primordia initiation was observed in the treatment $\mathrm{T}_{2} \mathrm{P}(9.33)$ followed by $T_{3} P(8.55) T_{1} P(8.50)$ and $T_{3} F$ and the lowest time from stimulation to primordia initiation was in the treatment $\mathrm{T}_{2} \mathrm{C}(7.33)$ and $\mathrm{T}_{1} \mathrm{C}(7.83)$. The other treatments were statistically similar (Table 1).

Table 1. Effect of different spawn seed on different variety on mycelia growth of oyster mushroom (Pleurotus ostreatus)

\begin{tabular}{|c|c|c|c|c|c|c|}
\hline \multirow[b]{2}{*}{ Treatments } & \multirow[b]{2}{*}{$\begin{array}{l}\text { Mycelium } \\
\text { running rate in } \\
\text { Spawn packet } \\
\text { (cm) }\end{array}$} & \multirow[b]{2}{*}{$\begin{array}{l}\text { Days required } \\
\text { to complete } \\
\text { mycelium } \\
\text { running }\end{array}$} & \multicolumn{4}{|c|}{ Time from (days) } \\
\hline & & & $\begin{array}{l}\text { Stimulation to } \\
\text { primordial } \\
\text { initiation }\end{array}$ & $\begin{array}{l}\text { Primordia } \\
\text { initiation to } \\
\text { Fruiting body } \\
\text { form }\end{array}$ & $\begin{array}{l}\text { Stimulation } \\
\text { to } \\
\text { harvest }\end{array}$ & $\begin{array}{c}\text { Total } \\
\text { harvest }\end{array}$ \\
\hline $\mathrm{T}_{1} \mathrm{C}$ & $0.54 b$ & $31.83 a$ & $7.83 \mathrm{~b}$ & $3.16 a$ & $11.00 \mathrm{a}$ & $62.00 \mathrm{ac}$ \\
\hline $\mathrm{T}_{2} \mathrm{C}$ & $0.58 a b$ & $21.00 d$ & $7.33 b$ & $3.50 a$ & $10.83 a$ & $58.33 d$ \\
\hline $\mathrm{T}_{3} \mathrm{C}$ & $0.59 a b$ & $25.67 \mathrm{~b}$ & $8.33 a b$ & $3.00 \mathrm{a}$ & $11.33 a$ & $59.67 \mathrm{bd}$ \\
\hline $\mathrm{T}_{1} \mathrm{~F}$ & $0.61 a$ & $21.67 \mathrm{~cd}$ & $8.16 a b$ & $3.50 \mathrm{a}$ & $12.17 \mathrm{a}$ & $52.67 e$ \\
\hline $\mathrm{T}_{2} \mathrm{~F}$ & $0.62 a$ & $20.67 d$ & $8.5 a b$ & $3.00 \mathrm{a}$ & $11.50 \mathrm{a}$ & $61.00 \mathrm{ad}$ \\
\hline $\mathrm{T}_{3} \mathrm{~F}$ & $0.62 a$ & $23.33 c$ & $8.5 a b$ & $2.83 a$ & $11.33 a$ & $62.67 a b$ \\
\hline $\mathrm{T}_{1} \mathrm{PO} 2$ & $0.62 a$ & $20.67 d$ & $8.5 a b$ & $2.66 a$ & $11.50 \mathrm{a}$ & $64.00 \mathrm{a}$ \\
\hline $\mathrm{T}_{2} \mathrm{PO} 2$ & $0.61 \mathrm{a}$ & $19.66 d$ & $9.33 a$ & $2.83 a$ & $11.83 a$ & $60.33 b d$ \\
\hline $\mathrm{T}_{3} \mathrm{PO} 2$ & $0.60 a b$ & $20.00 d$ & $8.55 a b$ & $3.33 a$ & $12.22 \mathrm{a}$ & $59.00 \mathrm{~cd}$ \\
\hline CV (\%) & 5.29 & 5.44 & 7.44 & 17.43 & 7.09 & 2.87 \\
\hline LSD & 0.05474 & 2.140 & 1.074 & 0.933 & 1.415 & 2.982 \\
\hline
\end{tabular}

Means followed by same letter significantly different at $1 \%$ or $5 \%$ level of significance.

$\mathrm{T}_{1} \mathrm{C}$ : Chickpea + Pleurotus cystidiosus

$\mathrm{T}_{3} \mathrm{~F}:$ Wheat + Pleurotus florida

$\mathrm{T}_{2} \mathrm{C}$ : Maize + Pleurotus cystidiosus

$\mathrm{T}_{1} \mathrm{PO} 2:$ Chickpea + Pleurotus ostreatus

$\mathrm{T}_{3} \mathrm{C}$ : Wheat + Pleurotus cystidiosus

$\mathrm{T}_{2} \mathrm{PO} 2:$ Maize + Pleurotus ostreatus

$\mathrm{T}_{1} \mathrm{~F}$ : Chickpea + Pleurotus florida

$\mathrm{T}_{2} \mathrm{~F}$ : Maize + Pleurotus florida

$\mathrm{T}_{3} \mathrm{PO} 2:$ Wheat + Pleurotus ostreatus

The highest time from primordia initiation to fruiting body formation was in the treatment $\mathrm{T}_{2} \mathrm{C}$ (3.51), $\mathrm{T}_{1} \mathrm{~F}$ (3.50) and $\mathrm{T}_{3} \mathrm{P}$ (3.33) and the lowest time from primordia initiation to fruiting body formation was observed in the treatment $T_{1} P(2.66)$ followed by $T_{3} F(2.83)$. The other treatments differed significantly over control (Table 1). The highest time from stimulation to harvest was observed in the treatment $T_{3} P(12.22) \& T_{1} F,(12.17)$ and $\mathrm{T}_{2} \mathrm{P}$ (11.83) and the lowest time from stimulation to harvest was in the treatment $\mathrm{T}_{2} \mathrm{C}$ (10.83). The other treatments differed significantly over control (Table 1). The lowest time for total harvest was observed in the treatment $T_{1} F(52.67)$ and $T_{2} C(58.33)$ and the maximum time for total harvest were in the treatment $T_{1} P$ (64.00). The other treatments differed significantly over control (Table 1). 
The present findings Corroborated with the findings of previous workers. (Khan et al., 1991; Kalita et al., 2001; Sarker, 2004). Khan et al reported that sawdust amended with different organic supplement like wheat chaff, wheat bran, paddy straw, cotton waste etc. provided suitable condition for spawn running. Sarker (2004) found that the mycelium running rate of oyster mushroom greatly influenced with the supplement of wheat brans in different levels. Kalita et al., (2001) reported that time taken for completion of spawn running may require to 17 days from 22 days by use of different substrates.

The effect of different substrates on different variety found to be significant in terms of time required for stimulation of spawn packet to primordia initiation. primordia initiation to harvest, stimulation of spawn packet to harvest and time required for total harvest varied significantly. Time from stimulation to primordial initiation (days) hightest in maize with Pleurotus ostreatus and lowest in maize Pleurotus cystidiosus. Time from primordia initiation to fruiting body formation is hightest in maize Pleurotus cystidiosus and lowest in chickpea with Pleurotus ostreatus. Time from stimulation to harvest (days) hightest in chickpea with Pleurotus florida lowest in maize Pleurotus cystidiosus. Time for total harvest (days) is hightest in maize pleurotus ostreatus and lowest in chickpea Pleurotus florida.

The results of the present findings keep in with the findings of the previous workers (Khan et al., 2001; Dhoke et al., 2001; Royse, 2002; Sarker, 2004; Ruhul Amin et al. 2007). Gupta (1986) found, the fruiting bodies appeared 12-15 days after the bags were removed, and the first crop was harvested 2-3 days later. Khan et al., (2001) reported that after spawn running pinhead formation took 7-10 days and fruiting body formed after 3-5 days, sporocarps may be harvested after 1 0-1 2 days. Dhoke et al. (2001) found significant effect of different agro-wastes on yield of oyster mushroom. The days required for first picking varied from 11.25-12.00 and the final picking complete from 42.25 to 43.50 days depending on different substrates. Royse, (2002) found, as the spawn rate increased the number of days to production decreased Sarker (2004) observed that duration from primordia initiation to first harvest of oyster mushroom was significantly lower as compared to control where no supplement was used and the duration required for total harvest of oyster mushroom increased with the substrate used. In the present study, the time required for total harvest also decreased with the levels of supplements increased compared to sawdust alone. Ruhul Amin et al. (2007) found significant differences among the level of supplements used for preparing the substrates.

Table 2. Effect of different spawn seed on different variety on yield and yield contributing characters of oyster mushroom (Pleurotus ostreatus)

\begin{tabular}{|lllllll|}
\hline \multirow{2}{*}{ Treatments } & \multicolumn{2}{l}{ Average number of } & & \multicolumn{2}{l}{$\begin{array}{l}\text { Length } \\
\text { of }\end{array}$} & $\begin{array}{l}\text { Diameter } \\
\text { of Pileus }\end{array}$ \\
\cline { 2 - 6 } & $\begin{array}{l}\text { Primordia/ } \\
\text { Packet }\end{array}$ & $\begin{array}{l}\text { Fruiting } \\
\text { body/ packet }\end{array}$ & $\begin{array}{l}\text { Effective fruiting } \\
\text { body/ packet }\end{array}$ & $\begin{array}{l}\text { Individual } \\
\text { fruiting body (g) }\end{array}$ & $\begin{array}{l}\text { Stalk } \\
\text { od }\end{array}$ \\
\hline $\mathrm{T}_{1} \mathrm{C}$ & $50.00 \mathrm{bd}$ & $40.33 \mathrm{ce}$ & $28.67 \mathrm{~d}$ & $5.84 \mathrm{ab}$ & $2.17 \mathrm{c}$ & $7.00 \mathrm{ab}$ \\
$\mathrm{T}_{2} \mathrm{C}$ & $43.67 \mathrm{~d}$ & $35.67 \mathrm{e}$ & $29.33 \mathrm{~cd}$ & $5.33 \mathrm{ab}$ & $4.33 \mathrm{ab}$ & $7.33 \mathrm{a}$ \\
$\mathrm{T}_{3} \mathrm{C}$ & $47.67 \mathrm{~cd}$ & $39.00 \mathrm{de}$ & $31.00 \mathrm{bd}$ & $4.83 \mathrm{~b}$ & $2.20 \mathrm{c}$ & $3.33 \mathrm{e}$ \\
$\mathrm{T}_{1} \mathrm{~F}$ & $55.00 \mathrm{bcd}$ & $43.67 \mathrm{ad}$ & $35.33 \mathrm{ab}$ & $5.22 \mathrm{ab}$ & $4.50 \mathrm{ab}$ & $5.83 \mathrm{ac}$ \\
$\mathrm{T}_{2} \mathrm{~F}$ & $58.00 \mathrm{bc}$ & $43.00 \mathrm{bd}$ & $35.33 \mathrm{ab}$ & $5.69 \mathrm{ab}$ & $2.66 \mathrm{c}$ & $3.83 \mathrm{de}$ \\
$\mathrm{T}_{3} \mathrm{~F}$ & $60.33 \mathrm{~b}$ & $48.67 \mathrm{ab}$ & $33.00 \mathrm{ad}$ & $6.08 \mathrm{ab}$ & $3.23 \mathrm{bc}$ & $5.50 \mathrm{bc}$ \\
$\mathrm{T}_{1} \mathrm{PO} 2$ & $61.00 \mathrm{~b}$ & $46.33 \mathrm{ac}$ & $36.33 \mathrm{ab}$ & $5.92 \mathrm{ab}$ & $4.80 \mathrm{a}$ & $6.00 \mathrm{ac}$ \\
$\mathrm{T}_{2} \mathrm{PO} 2$ & $58.67 \mathrm{bc}$ & $45.33 \mathrm{ad}$ & $34.33 \mathrm{ac}$ & $5.88 \mathrm{ab}$ & $2.23 \mathrm{c}$ & $2.83 \mathrm{e}$ \\
$\mathrm{T}_{3} \mathrm{PO} 2$ & $72.00 \mathrm{a}$ & $50.33 \mathrm{a}$ & $37.33 \mathrm{a}$ & $6.48 \mathrm{a}$ & $4.20 \mathrm{ab}$ & $5.16 \mathrm{~cd}$ \\
$\mathrm{CV}(\%)$ & $\mathbf{1 0 . 9 1}$ & $\mathbf{8 . 6 8}$ & $\mathbf{8 . 4 6}$ & $\mathbf{1 3 . 7 5}$ & $\mathbf{2 0 . 4 6}$ & $\mathbf{1 6 . 3 6}$ \\
$\mathrm{LSD}$ & 10.62 & 6.552 & 4.886 & 1.357 & 1.19 & 1.474 \\
\hline
\end{tabular}

Means followed by same letter significantly different at $1 \%$ or $5 \%$ level of significance

$\mathrm{T}_{1} \mathrm{C}:$ Chickpea + Pleurotus cystidiosus

$\mathrm{T}_{2} \mathrm{C}$ : Maize + Pleurotus cystidiosus

$\mathrm{T}_{3} \mathrm{C}:$ Wheat + Pleurotus cystidiosus

$\mathrm{T}_{1} \mathrm{~F}$ : Chickpea + Pleurotus florida

$\mathrm{T}_{2} \mathrm{~F}:$ Maize + Pleurotus florida
$\mathrm{T}_{3} \mathrm{~F}$ : Wheat + Pleurotus florida

$\mathrm{T}_{1} \mathrm{PO} 2$ : Chickpea + Pleurotus ostreatus

$\mathrm{T}_{2} \mathrm{PO} 2:$ Maize + Pleurotus ostreatus

$\mathrm{T}_{3} \mathrm{PO} 2$ : Wheat + Pleurotus ostreatus 


\section{Effect on yield contributing characters and yield}

\section{Primordia}

The highest average number of primordia/packet was observed in the treatment $\mathrm{T}_{3} \mathrm{P}(72.00)$ followed by $\mathrm{T}_{1} \mathrm{P}(61.20)$ and the lowest average number of primordia/packet was in the treatment $\mathrm{T}_{2} \mathrm{C}$ (43.67). The other treatments also differed significantly in terms of average number of primordia/packet (Table 2).

\section{Fruiting body}

The highest average number of fruiting body/packet was observed in the treatment $\mathrm{T}_{3} \mathrm{P}(50.33)$ and the lowest average number of fruiting body /packet was in the treatment $\mathrm{T}_{2} \mathrm{C}$ (35.67). The other treatments were similar in terms of average number of primordia/packet (Table 2).

\section{Effective fruiting body}

The highest average number of effective fruiting body/packet was observed in the treatment $\mathrm{T}_{3} \mathrm{P}(37.33)$ followed by $T_{1} F$ (35.33) and the lowest average number of effective fruiting body/packet was in the treatment $\mathrm{T}_{1} \mathrm{C}$ (28.67). The other treatments differed significantly in terms of average number of primordial/packet (Table 2).

\section{Individual fruiting body}

The highest average weight of individual fruiting body was observed in the treatment $T_{3} P(6.48)$ followed by $\mathrm{T}_{3} \mathrm{~F}$ (6.08) (5) and $\mathrm{T}_{1} \mathrm{C}(5.84)$ and the lowest average number of individual fruiting body was in the treatment $\mathrm{T}_{3} \mathrm{C}$ (4.83). The other treatments were statistically similar (Table 2).

\section{Diameter and Thickness of pileus}

Diameter and thickness of pileus under different treatments showed significant difference over control. The highest diameter of pileus was obtained in $\mathrm{T}_{2} \mathrm{C}(7.33 \mathrm{~cm})$ and $\mathrm{T}_{1} \mathrm{C}(7.00)$. The lowest diameter of pileus was obtained in $\mathrm{T}_{2} \mathrm{P}(2.83 \mathrm{~cm})$ and $\mathrm{T}_{3} \mathrm{C}(3.33)$.

\section{Length of stalk}

The highest length of stalk was obtained in $T_{1} P(4.80)$ and the lowest length was found in $T_{1} C(2.17 \mathrm{~cm})$ (Table 2).

\section{Biological, economic and dry yield}

The highest biological yield was counted under treatment $\mathrm{T}_{2} \mathrm{~F}(264.9)$ followed by $\mathrm{T}_{3} \mathrm{~F}(255.75 \mathrm{~g})$ and the lowest biological yield was counted under $\mathrm{T}_{1} \mathrm{C}$ (213.9). The rest of the treatments were statistically similar (Table 2). The highest economic yield was recorded under treatment $\mathrm{T}_{2} \mathrm{~F}(259.3 \mathrm{~g})$ followed by $\mathrm{T}_{3} \mathrm{~F}(250.7 \mathrm{~g})$ and the lowest economic yield was under $\mathrm{T}_{1} \mathrm{C}(209.4 \mathrm{~g})$. The rest of the treatments were statistically similar (Table 2). The dry yield of mushroom was maximum under the treatment $\mathrm{T}_{2} \mathrm{~F}(25.17 \mathrm{~g})$, that was followed by $\mathrm{T}_{3} \mathrm{~F}(24.43 \mathrm{~g})$. The lowest dry yield was recorded under $\mathrm{T}_{1} \mathrm{C}(20.29 \mathrm{~g})$ and $\mathrm{T}_{3} \mathrm{C}$ (20.48) (Table 2).

The effect of different substrates on different variety found to the significant in yield and yield contributing characters of oyster mushroom with some extent. Average number of primordia, fruiting body and effective fruiting body, weight of individual fruiting body and dimension of fruiting both significantly influenced with the substrate used. Average number of primordial, fruiting body and effective fruititig body, weight of individual fruiting body significantly influenced with the supplement of cow dung compared to sawdust alone.

The result of the present study corroborates with the study of previous researchers (Ahmed, 1998; Chowdhury et al., 1998; Baysal et al., 2003; Sarker et al., 2004.Habib, 2005; Dey, 2006: Ruhul Amin et al.,, 2007; Sarker et al, 2007), reported that the number of effective fruiting bodies was lower, but increased when the substrates was mixed with different supplements. Suitable amount of supplements added to sawdust medium maximized economic yield of oyster mushroom at optimum production cost. Ahmed (1998) reported significantly different number of primordia on different substrates. He observed significant effect of various substrates on diameter and Length of stalk also diameter and thickness of pileus. He also found that lower diameter of pileus produced the lowest yield and concluded that the diameter of pileus increased the quality and yield of mushroom and highest dry yield from mango sawdust. Chowdhury et al., (1998) examined the effects of adding different supplements to substrates growing oyster mushrooms (Pleurotus sajor caju) and found adding $5 \%$ supplements gave the highest yield of oyster mushroom. 
Baysal et al., (2003) found the highest yield of Oyster mushroom (Pleurotus ostreatus) with the substrate composed of $20 \%$ rice hush in weight. Sarker (2004) found that the number of primordial increased with the levels of supplement and continued up to a certain range and decline thereafter. Appreciable variations in economic yield also observed at different levels of supplements under different substrate- supplement combinations. He also found significant increase in weigh of fruiting body in gram per sporpcarps over control in spawn packet containing different supplement in compared with sawdust alone.

Habib (2005) who found that the diameter of pileus ranged from $4.85 \mathrm{~cm}$ to $8.95 \mathrm{~cm}$ and thickness of the pileus ranged from $0.45 \mathrm{~cm}$ to $0.70 \mathrm{~cm}$ due to different substrates. Habib (2005) mentioned that the stalk length of oyster mushroom on different substrate varied from $1.93 \mathrm{~cm}$ to $2.97 \mathrm{~cm}$ and the diameter ranged from $0.74 \mathrm{~cm}$ to $1.05 \mathrm{~cm}$. Dey (2006) found that the number of primordia and the average yield significantly varied with the substrates used in production of oyster mushroom. Ruhul Amin et al., (2004) found the highest biological yield $247.3 \mathrm{~g} /$ packet. He also found that the trend of economic yield corresponded with different supplements at different level. Sarker et al., (2007) found the range of dry yield from 4.28 to 29.98. He also reported the individual weight of fruiting body ranged from 1.33 to 1.59 but in the present study the individual weight of fruiting body ranged 4.83 to $6.48 \mathrm{~g}$. This might be due to environmental condition or due to different substrates used.

\section{Effect on biological efficiency and cost benefit ratio}

\section{Biological efficiency}

The highest biological efficiency of $86.90 \%$ was calculated in treatment $\mathrm{T}_{2} \mathrm{~F}$ which was followed by $\mathrm{T}_{3} \mathrm{P}$ $(86.07 \%)$ and the lowest biological efficiency of $74.26 \%$ was calculated from $\mathrm{T}_{1} \mathrm{C}$ and $75.37 \%$ was in $\mathrm{T}_{3} \mathrm{C}$. The rest of the treatments were statistically similar (Table 3 ).

Table 3. Effect of different spawn seed on different variety on yield contributing characters and yield of oyster mushroom (Pleurotus ostreatus)

\begin{tabular}{|llllll|}
\hline Treatments & $\begin{array}{l}\text { Biological } \\
\text { yield }(\mathbf{g})\end{array}$ & $\begin{array}{l}\text { Economic } \\
\text { yield }(\mathbf{g})\end{array}$ & Dry yield $(\mathbf{g})$ & $\begin{array}{l}\text { Biological } \\
\text { efficiency }\end{array}$ & Benefit cost ratio \\
\hline $\mathrm{T}_{1} \mathrm{C}$ & $213.9 \mathrm{~d}$ & $209.4 \mathrm{e}$ & $20.29 \mathrm{e}$ & $74.26 \mathrm{c}$ & $7.84 \mathrm{~d}$ \\
$\mathrm{~T}_{2} \mathrm{C}$ & $230.6 \mathrm{c}$ & $225.3 \mathrm{~d}$ & $21.82 \mathrm{~d}$ & $76.23 \mathrm{bc}$ & $8.32 \mathrm{~cd}$ \\
$\mathrm{~T}_{3} \mathrm{C}$ & $220.0 \mathrm{~cd}$ & $215.3 \mathrm{de}$ & $20.48 \mathrm{e}$ & $75.37 \mathrm{c}$ & $8.58 \mathrm{ac}$ \\
$\mathrm{T}_{1} \mathrm{~F}$ & $247.3 \mathrm{~b}$ & $241.8 \mathrm{bc}$ & $23.35 \mathrm{bc}$ & $82.00 \mathrm{ab}$ & $8.99 \mathrm{ab}$ \\
$\mathrm{T}_{2} \mathrm{~F}$ & $264.9 \mathrm{a}$ & $259.3 \mathrm{a}$ & $25.17 \mathrm{a}$ & $86.90 \mathrm{a}$ & $9.11 \mathrm{a}$ \\
$\mathrm{T}_{3} \mathrm{~F}$ & $255.5 \mathrm{ab}$ & $250.7 \mathrm{ab}$ & $24.43 \mathrm{ab}$ & $80.79 \mathrm{ac}$ & $8.95 \mathrm{ab}$ \\
$\mathrm{T}_{1} \mathrm{PO} 2$ & $255.3 \mathrm{ab}$ & $250.3 \mathrm{ab}$ & $23.64 \mathrm{bc}$ & $84.46 \mathrm{a}$ & $8.89 \mathrm{ab}$ \\
$\mathrm{T}_{2} \mathrm{PO} 2$ & $248.9 \mathrm{~b}$ & $244.7 \mathrm{bc}$ & $23.35 \mathrm{bc}$ & $83.14 \mathrm{a}$ & $8.48 \mathrm{bc}$ \\
$\mathrm{T}_{3} \mathrm{PO} 2$ & $243.3 \mathrm{~b}$ & $237.5 \mathrm{c}$ & $22.65 \mathrm{~cd}$ & $86.07 \mathrm{a}$ & $8.26 \mathrm{~cd}$ \\
$\mathrm{CV}(\%)$ & 2.80 & 44.52 & 3.29 & 4.33 & 3.41 \\
$\mathrm{LSD}$ & 11.74 & 11.55 & 1.299 & 6.075 & 0.507 \\
\hline
\end{tabular}

Means followed by same letter significantly different at $1 \%$ or $5 \%$ level of significance

$\mathrm{T}_{1} \mathrm{C}:$ Chickpea + Pleurotus cystidiosus

$\mathrm{T}_{3} \mathrm{~F}:$ Wheat + Pleurotus florida

$\mathrm{T}_{2} \mathrm{C}$ : Maize + Pleurotus cystidiosus

$\mathrm{T}_{3} \mathrm{C}$ : Wheat + Pleurotus cystidiosus

$\mathrm{T}_{1} \mathrm{PO} 2$ : Chickpea + Pleurotus ostreatus

$\mathrm{T}_{1} \mathrm{~F}$ : Chickpea + Pleurotus florida

$\mathrm{T}_{2}$ PO2: Maize + Pleurotus ostreatus

$\mathrm{T}_{2} \mathrm{~F}$ : Maize + Pleurotus florida 


\section{Cost Benefit ratio}

The highest cost benefit ratio was calculated in treatment $T_{2} F(9.1 \mathrm{I} \%)$ which was followed by $T_{1} F$ $(9.01 \%)$ and the lowest cost benefit ratio $7.84 \%$ was calculated from $\mathrm{T}_{1} \mathrm{C}$. The rest of the treatments were statistically similar (Table 3).

The effect of different substrates on different variety had great effect on biological efficiency and and benefit cost ratio (BCR) of oyster mushroom. The highest biological efficiency and benefit cost ratio (BCR) was shown in maize Pleurotus florida combination and lowest in chickpea Pleurotus cystidiosus and the other treatment had no significant difference on biological efficiency and and benefit cost ratio (BCR). The present findings keep in with the findings of previous workers (Biswas et al., 1997; Kalita et al., 997; Ahmed, 1998; Shen and Royse, 2001; Obodai et al., 2003; Mukesh et al., 2004; Sarker et al., 2007).

Biswas et al (1997) found supplementation of substrate promoted Biological efficiency (125.75\%). Kalita et al., (1997) observed biological efficiency for different substrates ranged from 35.2 to $60.9 \%$. Shen and Royse (2001) found supplements combined with basal ingredient results better musroom quality as well as biological efficiency. Obodai et al., (2003) biological efficiency (BE) followed a pattern and ranged from $61.0 \%$ to $80.0 \%$. Ahmed (1998) also observed the benefit cost ratio in case Pleurotus sajor caju. The cause of these variations between the results of this study might be due to consideration of other costs involved in the production of oyster mushroom or might be due to measuring system. Sarker et al., (2007) mentioned the performances of substrates were signilicanthy differed based on benefit cost ratio. They reported the highest cost benefit ratio of 6.50 with wheat straw.

\section{CONCLUSION}

The costly spawn or vegetative seed (Tk.8-10/packet) is one of the important constrain for the extension of mushroom production in the country. Therefore investigation on low cost spawn packets production for high yield and quality mushroom using available low cost spawn for the growers is an urgent demand. The effect of different spawn on different variety showed significant effect on mycelial running rate of oyster mushroom that reduced the required days to complete mycelium running in the spawn packet compared to the sawdust alone. The effect of different spawn on different variety found to be significant in yield and yield contributing characters of oyster mushroom with some extent. Average number of primordia, fruiting body and effective fruiting body, weight of fruiting body and dimension of fruiting body, yield, biological efficiency and benefit cost ratio (BCR) was showed higher in case of wheat with Pleurotus ostreatus, maize with Pleurotus florida. In this experiment more than one treatment performed better based on benefit cost ratio, therefore, aize with Pleurotus florida can be rccommended as an economically effective low cost spawn. On the other hand wheat with pleurotus ostreatus may be a fair option.

\section{ACKNOWLEDGEMENT}

The corresponding Author is very much grateful to the authority of Biochemistry Laboratory and Mushroom Culture House $(\mathrm{MCH})$ of the Department of Biochemistry, Sher-e Bangla Agricultural University, Dhaka-1207, Bangladesh for supervision and allowing conducting the experiment to accomplish the research.

\section{CONFLICT OF INTEREST}

There is no conflict of interest in this study. 


\section{REFERENCES}

1. Ahmed S, 1998. Performance of different substrates on the growth and yield of Oyster mushroom (Pleurotus sajor-caju (Fr.) Sing).M.S. thesis, Institute of Postgraduate Studies in Agriculture, Salna, Gazipur.

2. Al-Amin MA, 2004. Studies on mycelium, spawn and production of certain edible mushrooms. M.S.Thesis, Department of Biotechnology, BAU. Mymensingh.

3. Alam SM and R Sahoohi 2001. Importance of mushroom. http:// www. mushroom world.Com

4. Baysal U, Peker, H, Yalinkilic MK, Temiz A, 2003. Cultivation of Oyster mushroom on waste paper with some added supplementary materials. Bioresource Technology, 89(1): 95-97.

5. Biswas MK, Shukia CS and Kumar SM, 1997. Method for increasing biological efflcicncy of Oyster mushroom (Pleurotus florida) in Madhya Pradesh. Advances in Plant Science, 10 (1): 69-74.

6. Chowdhury AK, BN Panja and SK Laha, 1998. Organic supplements for better yield of oyster mushroom. Journal of Interacademicia, 2(1 -2): 116-117.

7. Dey RC, 2006. Mycelial Growth and Oyster Mushroom Production with Different Hormone and Media Composition. M S. thesis, Department of Biotechnology, BAU. Mvmensingh.

8. Dhoke PK, Chavan RA and VT Jadhay 2001. Cropping period and yield of Oyster mushroom (Pleurotus sajor caju) on different agro-substrate. Madras Agricultural Journal, 88(4-6): 327-329.

9. Gupta RS 1986. Mushroom Cultivation. Indian Horticulture, 31(1): 11.

10. Habib MA, 2005. Comperative study on cultivation and yield Performance of Oyster Mushroom (Pleurotus ostreatus) on different substrates. M. S. Thesis, Department of Biotechnology, BAU, Mymensingh.

11. Kalita MK, Rathaiah $Y$ and Bhagahati, KN 1997. Effects of Some agro wastes as substrate for Oyster mushroom (Pleurotus sajor-caju) cultivation in Assam. Indian J. Hill Farming. 10 (1-2): 109-110.

12. Khan AM and SM Khan 2001. Studies on the cultivation of Oyster mushroom Pleurotus ostreatus on different substrate Pakistan. Journal of Phytopathology, 13 (2): 140-143.

13. Kovfeen C 2004. Economic Times. http//www.techno-preneur.net.

14. Labuschagne PMA, TAS Licker Aveling, S deMeillon and MF Smith, 2000. Influence of wheat cultivars on straw quality and Pleurotus ostreatus cultivation. Journal of Bioresource Technology, $7 \mathrm{l}(\mathrm{I}): 71-75$.

15. Mori K 1986. Cultivated mushrooms in .Japan. Proc. Int'l Sym Sci. Tech. Aspects of Culti . Edible Fungi Penna State Univ., USA pp 2 1-24.

16. Mukesh SK, Das SR and BK Pani, 2004. Effect of pretreatment of substrate on the yield of oyster mushroom (Pleurotus sajor caju (Fr.) Singer). Journal of Mycopathological Research, 36 (2): 113114.

17. Obodai M, Okine C, KA Vowotor 2003. Comparative study on the growth and yield of Pleurotus ostreatus mushroom on different lignocellulosic by-products. Food Res. Inst. Accra, Ghana. Journal of Industrial Microbiology and Biotechnology, 30 (3): I 46-149.

18. Royse DJ 2002. Influence of spawn rate and commercial delayed release nutrient levels on Pleurotus cornoucopiae (oyster mushroom) yield, size and time to production. Applied Microbiology and Biotechnology, 58 (4): 52 7-531.

19. Ruhul Amin SM, MM Rahman, MM Hossain, M Moynul Haque and Nirod Chandra Sarker 2007. Effect of Different Substrates on the Growth and yield of five Selected oyster mushroom Bangladesh Journal of Mushroom, 1(2): 39-43.

20. Ruhul Amin SM Nirod Chandra Sarker, Abul Khair and Nuhu Alam 2007. Detection of Novel Supplements on Paddy Straw Substrates on Oyster Mushroom Cultivation. Bangladesh Journal of Mushroom, 1(2): 18-22.

21. Sarker NC, Hossain MM, Sultana N, Mimi H, Sitazul Karim AJM and SM Ruhul Amin 2007. Performance of Different Substrates on the growth and Yield of Pleurotus ostreatus (Jacquin cx Fr.) Kummcr. Bangladesh Journal of Mushroom, 1(2): 44-49. 